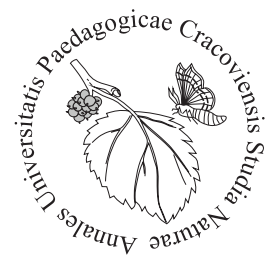

Annales Universitatis Paedagogicae Cracoviensis Studia Naturae, 3 (supplement): 17-23, 2018, ISSN 2543-8832

DOI: $10.24917 / 25438832.3$ supp.2

Anna Čuvalováa ${ }^{\star}$, Imrich Strapáč², Lívia Handrová', Vladimír Kmet¹ ${ }^{1}$ Institute of Animal Physiology, Centre of Biosciences of the SAS, Soltesovej 4/6, 04001 Kosice, Slovak Republic, * ${ }^{*}$ cuvalova@saske.sk ${ }^{2}$ Department of Chemistry, Biochemistry and Biophysics, Institute of Pharmaceutical Chemistry, University of Veterinary Medicine and Pharmacy, Komenskeho 73, 04181 Kosice, Slovak Republic

\title{
Antibiofilm activity of mushroom extracts against Staphylococcus aureus F. J. Rosen.
}

Introduction

In recent years, a growing interest has developed in the mechanisms of the action of natural products, because they are a major source of chemical diversity and have provided important therapeutic agents for many bacterial diseases (Payne et al., 2007). Mushrooms have long been appreciated for their taste, flavour, desirable aroma, texture, and nutraceutical and medicinal attributes (Strapáč et al., 2016). Moreover, they are a renowned source of products with an array of bioactivities, from antibacterial to antiviral, cytotoxic, anti-inflammatory, anti-feeding, antifungal or antioxidant and might be a valuable resource in the search of new bioactive extracts to inhibit biofilm production (Martín-Rodríguez et al., 2014; Alves et al., 2014). In this context, flavonoids and phenolic compounds have been revealed as potential inhibitors of biofilm formation and the production of virulence factors in the pathogenic bacteria by interfering with quorum sensing mechanisms (Nazzaro et al., 2013).

The main factors associated with biofilm formation are the iron uptake system and adhesive matrix proteins. Adhesion is favoured by the presence of virulence factors known as adhesins, which are grouped in a family known as the microbial surface components recognising adhesive matrix molecules (MSCRAMM). Major proteins adhesins in this group include fibronectin binding proteins $\mathrm{A}$ and $\mathrm{B}(\mathrm{FnBpA}, \mathrm{FnBpB})$, bone sialoprotein binding protein (Bbp), iron regulated surface determinants $\mathrm{A}$ and $\mathrm{B}$ (IsdA, $\mathrm{IsdB}$ ), and serine aspartate repeat gene proteins $\mathrm{D}$ and $\mathrm{E}$ ( $\mathrm{SdrD}$, SdrE) (Rasmussen et al., 2013; Cucarella et al., 2001). Staphylococcus aureus F. J. Rosen also produces cytotoxins and hemolysins $(\alpha, \beta, \gamma$ and $\delta$ ), which possess the ability to form pores in host cells enabling lysis. In staphylococci, the expression of a series of toxins and virulence factors are controlled by the accessory gene regulator (Agr) system (Jarraud et al., 2002). 
In the present study, a water extract obtained from a sample of Macrolepiota procera (Scop.) Singer, Pleurotus ostreatus (Jacq.) P. Kumm., Auricularia auricula-judae (Bull.) Quél., Armillaria mellea (Vahl) P. Kumm. and Laetiporus sulphureus (Bull.) Murrill was explored for its antibiofilm activity against Staphylococcus aureus strains.

Material and methods

Bacterial strains

The following staphylococci strains were used in this study from our own laboratory: Staphylococcus aureus No. 5 and S. aureus No. 51, isolated from ixodid ticks (Acari); S. aureus No. 12, and S. aureus No. 14, isolated from ewe's milk. All cultures were identified by matrix-assisted laser desorption/ ionization (MALDI) biotyper (Bruker Daltonik, Leipzig, Germany). All staphylococci strains were cultured at $37^{\circ} \mathrm{C}$ on blood agar (Blood agar base No. 2, Oxoid, Basingstoke, United Kingdom and with 5\% defibrinated sheep blood).

Mushroom extracts

The preparation of mushrooms water extracts were determined as described previously (Strapáč et al., 2016). For our analysis, we used $1 \mathrm{~kg}$ of freshly harvested fruiting bodies of Macrolepiota procera, Armillaria mellea and Laetiporus sulphureus, collected in the autumn of 2014 in an area of Dargov, Bankov near Košice and Ižkovice, respectively, in the Slovak Republic. The last two are commercially available mushrooms, Pleurotus ostreatus and Auricularia auricula-judae. Water extracts were prepared by the extraction of $100 \mathrm{mg}$ samples in $2 \mathrm{~cm}^{3}$ of water for $24 \mathrm{~h}$ with occasional vigorous stirring at $8^{\circ} \mathrm{C}$ in a refrigerator. Then, the extracts were filtered and stored at $4^{\circ} \mathrm{C}$.

Biofilm production assay For the detection of biofilm formation, the crystal violet method with Nunc Maxisorp plates were used (Nunc, Roskilde, Denmark) by a previously published method (O'Toole, 2011) with some modifications. Overnight cultures of Staphylococcus aureus were removed from each well and 3 times washed with saline, fixed with methanol, and stained with $0.1 \%$ crystal violet. The bound dye was released with $33 \%$ acetic acid, and the optical density (OD) at $570 \mathrm{~nm}$ was measured by using a Synergy HT Multi-Mode Microplate Reader (BioTek, Winooski, Vermont, USA).

Anti-biofilm activity of mushroom extracts To detect the effects of mushrooms water extracts of Macrolepiota procera, Pleurotus ostreatus, Auricularia auricula-judae, Armillaria mellea, and Laetiporus sulphureus on staphylococcal biofilm formation, $10 \mu \mathrm{l}$ of extracts were added to the each well and 
the plates were incubated $24 \mathrm{~h}$ at $37^{\circ} \mathrm{C}$. The biofilm quantification has been described above. Wells containing medium were used as blank controls. The percentage of the inhibition of biofilm formation was calculated according to the following equation: (1 - OD590 of test / OD590 of untreated control) $\times 100 \%$.

\section{Polymerase chain reaction}

The presence of virulence genes of staphylococci was carried out by polymerase chain reaction (PCR). Strains were screened for the following genes: $\alpha$-hemolysin gene ( $h l a)$ as described by (Jarraud et al., 2002), serine-aspartate repeat proteins E gene ( $s d r E$ ) (Sabat et al., 2006), iron-regulated surface determinants A gene (isdA) (Verkaik et al., 2010) and B gene (isdB) (Waryah et al., 2016), bone sialoprotein - binding protein gene $(b b p)$ (Tristan et al., 2003), fibronectin- binding protein A gene ( $f n b p A)$ (Booth et al., 2001), iron-siderophore transporter gene (sirB) (Dale et al., 2004), and accessory gene regulator (agr II) (Shopsin et al., 2003).

\section{Statistical analysis}

All assays were performed in eight replicates and the means as well as the standard deviations were calculated. A one-way analysis of variance (ANOVA) and Tukey's test were used to compare data utilising Statistica 9.0 software (StatSoft, Tulsa, Oklahoma, USA).

Results

In present study, genes hla and isdA were found to occur in all Staphylococci. The presence of $s d r E$ gene was detected in three out of four strains. Genes agrII, is $d B$, $b b p$ and $s i r B$ were only detected in strains isolated from ixodid ticks. Gene $f n b p A$ was detected in Staphylococcus aureus No. 51. The biofilm formation of $S$. aureus strains was reduced by all mushrooms extracts without affecting the bacterial growth. The best results were observed for the Armillaria mellea (70.87\%), Pleurotus ostreatus (67.00\%), Laetiporus sulphureus (64.14\%) and Auricularia auricula-judae (62.77\%), while Macrolepiota procera showed the lowest reduction of biofilm formation $(47.72 \%)$. The extracts reduced biofilm formation in the range of $47.72-70.87 \%$, which means that the biofilm was formed in the presence of extracts in the range of 29.13-52.28\%. We showed that a more significant anti-biofilm effect of the extracts, except for M. procera, was of Staphylococcus aureus isolated from ixodid ticks (82.00\%) in comparison to S. aureus isolated from ewe's milk (50.00\%) (Tab. 1). The extract from $M$. procera had a similar effect on strains isolated from ixodid ticks (46.50\%) and ewe's milk (49.00\%). 
Tab. 1. The effect of mushrooms extracts on biofilm formation of Staphylococcus aureus F. J. Rosen. 5 isolated from ixodid ticks; significant differences are indicated with asterisks $\left(^{*}-\mathrm{p}<0.05\right.$, ${ }^{* *}-\mathrm{p}<0.01$, $* * *-\mathrm{p}<0.001$, Tukey's test)

\begin{tabular}{lcc}
\hline Name of mushrooms & Mean value $\mathrm{n}=8$ & Standard deviation $( \pm \mathrm{SD})$ \\
\hline Control & 0.216 & 0.100 \\
Armillaria mellea & $0.037^{* *}$ & 0.006 \\
Laetiporus sulphureus & $0.042^{* *}$ & 0.014 \\
Pleurotus ostreatus & $0.025^{* * *}$ & 0.009 \\
Auricularia auricula-judae & $0.039^{* *}$ & 0.010 \\
Macrolepiota procera & 0.150 & 0.048 \\
\hline
\end{tabular}

Discussion

We investigated the main factors associated with biofilm formation. The results of our study are in agreement with Kateete et al. (2011) who reported that $100 \%$ isolates had hla gene and with Verkaik et al. (2010) who reported that $100 \%$ isolates had isdA gene. Tristan et al. (2003) reported positivity rates of $f n b A$ and bbp among Staphylococcus aureus isolates $28.00 \%$ and $22.00 \%$. Liu et al. (2015) showed that $68.10 \%$ of isolates contained the $s d r E$ gene.

Our study focused on the antibiofilm activity of mushrooms extracts. We have confirmed here the great potential of mushrooms to produce antibiofilm compounds, and we showed good antibiofilm effects of aqueous extracts in terms of the reduction of biofilm formation. Similar observations have been made previously by others with different bacteria (Kostić et al., 2017), and showed the antibiofilm activity of Armillaria mellea extract against Pseudomonas aeruginosa. Antibiofilm activity was associated with content of phenolic compounds and organic acids. Another study that worked on the organic extracts of Macrolepiota procera and Laetiporus sulphureus showed antibiofilm activity against $S$. aureus (Carvalho et al., 2015). Li and Dong (2010) reported the inhibition of Escherichia coli T. Escher. biofilm formation (73.00\%) by Auricularia auricula-judae extract. This is a pioneer study since, as far as we know, there are no reports on the antibiofilm activity by the mushroom extracts of Pleurotus ostreatus, against $S$. aureus; nevertheless, other studies are required to elucidate the mechanism of action.

\section{Conclusion}

Extracts from mushrooms are a complex of different chemical compounds. An identification and understanding of the mechanisms of mushrooms extracts action will enable their further application to new innovative strategies for the control of microbial contamination and infection via the food chain. 
This study was supported by the Slovak projects APVV 14-0274 and VEGA 2/0085/18.

\section{Acknowledgement}

References

Alves, M.J., Ferreira, I.C.F.R., Lourenço, I., Costa, E., Martins, A., Pintado, M. (2014). Wild Mushroom Extracts as Inhibitors of Bacterial Biofilm Formation. Pathogens, 3, 667-679. DOI: 10.3390/pathogens3030667

Booth, M.C., Pence, L.M., Mahasreshti, P., Callegan, M.C., Gilmore, M.S. (2001). Clonal associations among Staphylococcus aureus isolates from various sites of infection. Infection and Immunity, 69(1), 345-352. DOI: 10.1128/iai.69.1.345-352.2001

Carvalho, M.P., Türck, P., Abraham, W.R. (2015). Secondary Metabolites Control the Associated Bacterial

Communities of Saprophytic Basidiomycotina Fungi. Microbes and environments, 30, 196-198. DOI: 10.1264/jsme2.ME14139

Cucarella, C., Solano, C., Valle, J., Amorena, B., Lasa, I., Penadés, J.R. (2001). Bap, a Staphylococcus aureus

surface protein involved in biofilm formation. Journal of Bacteriology, 183, 2888-2896. DOI: 10.1128/ JB.183.9.2888-2896.2001

Dale, S.E., Sebulsky, M.T., Heinrichs, D.E. (2004). Involvement of SirABC in iron-siderophore import in Staphylococcus aureus. Journal of Bacteriology, 186(24), 8356-8362. DOI: 10.1128/JB.186.24.83568362.2004

Jarraud, S., Mougel, C., Thioulouse, J., Lina, G., Meugnier, H., Forey, F., Nesme, X., Etienne, J., Vandenesch, F. (2002). Relationships between Staphylococcus aureus genetic background, virulence factors, agr groups (alleles), and human disease. Infection and immunity, 70(2), 631-641. DOI: 10.1128/ IAI.70.2.631-641.2002

Kateete, D.P., Namazzi, S., Okee, M., Okeng, A., Baluku, H., Musisi, N.L., Katabazi, F.A., Joloba, M.L., Ssentongo, R., Najjuka, F.C. (2011). High prevalence of methicillin resistant Staphylococcus aureus in the surgical units of Mulago hospital in Kampala, Uganda. BMC Research Notes, 4(326). DOI: $10.1186 / 1756-0500-4-326$

Kostić, M., Smiljković, M., Petrović, J., Glamočlija, J., Barros, L., Ferreira, I.C.F.R., Ćirić, A., Soković, M. (2017). Chemical, nutritive composition and a wide range of bioactive properties of honey mushroom Armillaria mellea (Vahl: Fr.) Kummer. Food and function, 8, 3239-3249. DOI: 10.1039/c7fo00887b

Li, B., Dong, M. (2010). Inhibition of Escherichia coli biofilm by Auricularia auricula extract. Modern Food Science and Technology, 26, 1067-1070.

Liu, H., Lv, J., Qi, X., Ding, Y., Li, D., Hu, L., Wang, L., Yu, F. (2015). The carriage of the serine-aspartate repeat protein-encoding $s d r$ genes among Staphylococcus aureus lineages. Brazilian Journal of Infectious Diseases, 19, 498-502. DOI: 10.1016/j.bjid.2015.07.003

Martín-Rodríguez, A.J., Reyes, F., Martín, J., Pérez-Yépez, J., León-Barrios, M., Couttolenc, A., Espinoza, C., Trigos, A., Martín, V.S., Norte, M., Fernández, J.J. (2014). Inhibition of bacterial quorum sensing by extracts from aquatic fungi: first report from marine endophytes. Marine Drugs, 12, 5503-5526. DOI: $10.3390 / \mathrm{md} 12115503$

Nazzaro, F., Fratianni, F., Coppola, R. (2013). Quorum Sensing and Phytochemicals. International Journal of Molecular Sciences, 14, 12607-12619. DOI: 10.3390/ijms140612607

O’Toole, G.A. (2011). Microtiter dish biofilm formation assay. Journal of Visualized Experiments, 47. DOI: $10.3791 / 2437$

Payne, D.J., Gwynn, M.N., Holmes, D.J., Pompliano, D.L. (2007). Drugs for bad bugs: confronting the challenges of antibacterial discovery. Nature reviews. Drug Discovery, 6(1), 29-40. DOI: 10.1038/ $\operatorname{nrd} 2201$ 
Rasmussen, G., Monecke, S., Ehricht, R., Söderquist, B. (2013). Prevalence of clonal complexes and virulence genes among commensal and invasive Staphylococcus aureus isolates in Sweden. PLoS One, 9, (e99097). DOI: 10.1371/journal.pone.0077477

Sabat, A., Melles, D.C., Martirosian, G., Grundmann, H., van Belkum, A., Hryniewicz, W. (2006). Distribution of the serine-aspartate repeat protein-encoding $s d r$ genes among nasal-carriage and invasive Staphylococcus aureus strains. Journal of Clinical Microbiology, 44(3), 1135-1138. DOI: 10.1128/ JCM.44.3.1135-1138.2006

Shopsin, B., Mathema, B., Alcabes, P., Said-Salim, B., Lina, G., Matsuka, A., Martinez, J., Kreiswirth, B.N. (2003). Prevalence of agr specificity groups among Staphylococcus aureus strains colonizing children and their guardians. Journal of Clinical Microbiology, 41(1), 456-459. DOI: 10.1128/JCM.41.1.456459.2003

Strapáč, I., Baranová, M., Smrčová, M., Bedlovičová, Z. (2016). Antioxidant activity of honey mushrooms (Armillaria mellea). Folia Veterinaria, 60(4), 37-41. DOI: 10.1515/FV-2016-0036

Tristan, A., Ying, L., Bes, M., Etienne, J., Vandenesch, F., Lina, G. (2003). Use of multiplex PCR to identify Staphylococcus aureus adhesins involved in human hematogenous infections. Journal of Clinical Microbiology, 41(9), 4465-4467. DOI: 10.1128/JCM.41.9.4465-4467.2003

Verkaik, N.J., Boelens, H.A., de Vogel, C.P., Tavakol, M., Bode, L.G., Verbrugh, H.A., van Belkum, A., van Wamel, W.J. (2010). Heterogeneity of the humoral immune response following Staphylococcus aureus bacteremia. European Journal of Clinical Microbiology \& Infectious Diseases, 29(5), 509-518. DOI: 10.1007/s10096-010-0888-0

Waryah, C.B., Gogoi-Tiwari, J., Wells, K., Eto, K.Y., Masoumi, E., Costantino, P., Kotiw, M., Mukkur, T. (2016). Diversity of virulence factors associated with West Australian methicillin-sensitive Staphylococcus aureus isolates of human origin. BioMed Research International, 1-10. DOI: $10.1155 / 2016 / 8651918$

Abstract

Mushrooms are a renowned source of products with an array of bioactivities, from antibacterial to antiviral, cytotoxic, anti-feeding, antifungal, or antioxidant and might be a valuable resource in the search of new bioactive extracts to inhibit biofilm production. We demonstrate the effect of five mushroom water extracts, Macrolepiota procera, Pleurotus ostreatus, Auricularia auricula-judae, Armillaria mellea, and Laetiporus sulphurous on biofilm formation of four Staphylococcus aureus strains isolated from ixodid ticks (Acari) and ewe's milk. The PCR was used for the detection of virulence genes ( $h l a, i s d A, B, b b p$, sirB, fnbpA, sdrE, agr II). The ability of biofilm formation and anti-biofilm activity of mushrooms extracts was assessed in a quantitative crystal violet assay. The biofilm formation of $S$. aureus strains was significantly reduced by all mushrooms extracts $(\mathrm{p}<0.001)$. We showed that a more significant anti-biofilm effect of the extracts was of Staphylococcus aureus isolated from ixodid ticks in comparison to Staphylococcus aureus isolated from ewe's milk. In the present study, A. mellea, P. ostreatus, L. sulphurous, A. auricula-judae, and M. procera extracts inhibited biofilm formation by $70.87 \%, 67.00 \%, 64.14 \%, 62.77 \%$ and $47.71 \%$, respectively. The results suggest that compounds in mushrooms extracts might be useful to control and handle detrimental infections caused by animal and human pathogens.

Key words: biofilm, fungi, ixodid ticks (Acari), milk, Staphylococcus aureus

Received: [2018.05.30]

Accepted: [2018.11.12] 
Grzyby są znanym źródłem produktów bioaktywnych - począwszy od środków przeciwbakteryjnych po przeciwwirusowe, cytotoksyczne, przeciwlękowe, przeciwgrzybicze lub przeciwutleniające. Mogą być cennym źródłem nowych bioaktywnych ekstraktów poszukiwanych w celu zahamowania produkcji biofilmu bakteryjnego. W pracy pokazano wpływ pięciu wodnych ekstraktów z Macrolepiota procera, Pleurotus ostreatus, Auricularia auricula-judae, Armillaria mellea i Laetiporus sulphurous na tworzenie się biofilmu czterech szczepów Staphylococcus aureus, izolowanych z kleszczy (Acari) i mleka owczego. Do wykrywania genów wirulencji ( $h l a$, isdA, $B, b b p$, sir $B$, fnbp $A$, sdrE, agr II) zastosowano metodę PCR. Zdolność tworzenia biofilmów i aktywność anty-biofilmową ekstraktów grzybów oceniano w analizie ilościowej fioletem krystalicznym. Tworzenie biofilmu szczepów $S$. aureus było znacznie mniejsze w środowisku ekstraktów z grzybów ( $\mathrm{p}<0,001)$. Wykazaliśmy, że bardziej wrażliwy na działanie anty-biofilmowe ekstraktów grzybów był $S$. aureus wyizolowany z kleszczy niż wyizolowany z mleka owczego. W niniejszych badaniach, A. mellea, P. ostreatus, L. sulphurous, A. auricula-judae i M. procera, hamowały tworzenie się biofilmu (o odpowiednio 70,87\%, 67,00\%, 64,14\%, 62,77\% i 47,71\%). Wyniki sugerują, że związki zawarte w wodnych ekstraktach z grzybów mogą być przydatne do kontrolowania i zwalczania szkodliwych infekcji powodowanych przez patogeny zwierzęce i ludzkie.

Słowa kluczowe: biofilm, grzyby, kleszcze (Acari), mleko, Staphylococcus aureus

\section{Information about authors}

\section{Anna Čuvalová}

She is interested in anti-biofilm activities of natural compounds using the static and dynamic biofilm models with resistant staphylococci (MRSA and MRCoNS), Escherichia coli (ESBL and cefotaximases) and Pseudomonas aeruginosa on various surfaces (plastics, catheters and food grade stainless sheet).

\section{Imrich Strapáč}

$\mathrm{He}$ is interested in biofilm and anti-biofilm activities of natural compounds using the static and dynamic biofilm models with Escherichia coli, and resistant staphylococci (MRSA and MRCoNS). The area of his interest is genetic ecology and genes encoding factors of virulence, metabolism, and the spreading of these genes. He studies the resistance occurrence in animal, which could serve as a reservoir of antibiotic resistance in indicator bacteria.

Lívia Handrová http://orcid.org/0000-0002-0985-1771

The main area of her interest is genetic ecology and the spread of antibiotic resistance genes. She studies the resistance occurrence in small mammals, which could serve as a reservoir of antibiotic resistance (ESBL, plasmid encoded chinolone resistance, carbapenemases) in indicator bacteria Escherichia coli, Pseudomonas aeruginosa and Staphylococcus spp.

Vladimír Kmet' http://orcid.org/0000-0002-8081-8579

$\mathrm{He}$ is interested in biofilm and anti-biofilm activities of natural compounds using the static and dynamic biofilm models with Escherichia coli, resistant staphylococci (MRSA and MRCoNS). The area of his interest is genetic ecology and gene encoding factors of virulence, metabolism, and the spreading of these genes. He studies the resistance occurrence in animal, which could serve as a reservoir of antibiotic resistance in indicator bacteria. 